\title{
Canadian Immigrant Youth and the Education-Employment Nexus
}

\author{
Leslie Nichols, Belinda Ha, and Vappu Tyyskä
}

\begin{abstract}
Canada's population of immigrant youth between the ages of 15 and 35 is approaching 3 million and growing rapidly. Youth are critical to Canada's goal of recruiting immigrants to expand the economy, but there is insufficient information about their school and work experiences and inadequate support to ensure their successful integration into the workforce. This literature review investigates the connection between education and work for Canadian immigrant youth. It documents obstacles in the form of underfunded settlement services, lack of diversity in the school curriculum, inadequate English-language instruction at all levels of schooling, racially and ethnically biased streaming of students into the lowest educational track in high school, rejection of foreign school transcripts and work credentials, employers' prejudice and discrimination, and workplace exploitation. The number and magnitude of these systemic impediments create significant obstacles for immigrant youth. A major cause of these issues is insufficient funding for immigrant services under neoliberal economic policies. The outcomes for immigrant youth include failure to finish secondary and postsecondary education, a long-term cycle of employment in low-skill, low-wage jobs, and socioeconomic hardship such as poverty and homelessness. The authors call for greater attention to this critical population and make nine recommendations that would contribute to solutions in each major issue area impacting the education of Canadian immigrant youth and their entry into the workforce.
\end{abstract}

Keywords: Canadian immigrant youth, settlement services, immigrant students streaming, racism in schools, ESL services

Leslie Nichols is a Faculty Researcher at Georgian College. She has a PhD in policy studies and specializes in labour and women's studies. She has conducted mixed-method studies of marginalized groups in the Canadian workforce, women's time poverty, newcomer settlement, and Canadian immigration policy.

Belinda $\mathrm{Ha}$ is a PhD candidate at Ryerson University. Her current research examines the private sponsorship of refugees in Canada.

Vappu Tyyskä is Professor Emerita of Sociology at Ryerson University with affiliations in the MA Program in Immigration and Settlement Studies and PhD in Policy Studies. 
Nichols, Ha, and Tyyskä

\section{Introduction}

As Canada's immigrant population grows as a result of admission of refugees and recruitment of educated, skilled workers needed to support economic growth, so does its population of young immigrants. In 1996, there were 429,100 first-generation immigrant youth between the ages of 15 and 24 in Canada (11.4\% of the total youth population; Canadian Council on Social Development, 2006). As of the 2016 census, that number had risen to 759,025 (17.94\% of the youth population; Statistics Canada, 2019c), and there were more than two million immigrant youth between 15 and 35 (Statistics Canada, 2018).

All youth need targeted skills training that leads to employment and financial selfsufficiency as well as support with their transition from secondary and postsecondary education to the job market. Canadian immigration policy for the economic class centers on adult males. Given the large size of the Canadian immigrant youth population and the importance of their future economic contributions, it is imperative to consider the specific needs of immigrant youth as future workers. The limited data available points to marginalization of newcomer youth as a result of streaming them into education programs that lead to low-skilled, low-wage jobs; long-standing discriminatory practices in the labour market based on prejudices around immigrants, race, language, and culture; rejection of their foreign education and work credentials; and deskilling, or placement in jobs below their education and skills. Thus, they face hurdles to school and work that go beyond the difficulties of native-born youth and they deal with "double jeopardy: being new and being young" (Francis \& Yan, 2016, p. 78).

This article investigates the current socioeconomic status of immigrant youth in Canada and their experiences with school and work and suggests policy changes to ensure that immigrant youth have equitable access to quality education and jobs to fulfill their potential on par with native-born Canadians.

\section{Key Demographics: Who are Canadian Immigrant Youth?}

The age demarcation of "youth" varies by country and institution. Statistics Canada defines youth as 15 to 24 years old (Moyser, 2017), separating them from the core-working-age group of 25 to 54. Many scholars (Tyyskä, 2014; Nichols, 2018) favour a wider range of 15 to 35 to account for the trend of youth remaining in school and under their parents' roof longer, resulting in later entry into the job market and delaying marriage and having children. This article adopts the greater age range for that reason.

The term immigrant also needs definition. First, ideally, we should distinguish between youth who migrate alone as unaccompanied minors and those who come to Canada with their parents, because the needs of those two groups are vastly different. Studies of immigrant youth often do not distinguish between those categories, making it difficult to ascertain their socioeconomic status. Canada received 287 unaccompanied refugee minors in 2016 and 492 in 2017; the Immigration and Refugee Board of Canada does not have data for prior years (Walji, 2018). The existing data seem to indicate that there are several thousand unaccompanied refugee minors in Canada. A 2013 investigation by the Toronto Star (Hayes, 2013) estimated that the figure 
could be as high as 3,000 unaccompanied minors per year. Currently there are no statistics for the number of unaccompanied youth because Statistics Canada includes only youth up to age 18 in the "minors" group and does not document the age of unaccompanied people over age 18. This is an important missing statistic because of the unique needs of youth over 18, who may require more supports than older adults. The lack of statistics may indicate a lack of understanding of this distinct age group.

At present there are no clear federal policies for dealing with unaccompanied minors. Some immigration policies make it difficult to reunite young immigrants with their families, such as a policy barring sponsorship of nonbiological children. Many of these minors have experienced war and other traumas in countries like Syria. In 2016 researchers at the International Human Rights Program at the University of Toronto (Gros \& Song, 2016) released a report confirming that Canada had detained unaccompanied minors for immigration violations, including two 16-yearold boys who were held in solitary confinement at the Toronto immigration holding centre. These experiences of compound trauma have a severe psychological impact on immigrant youth (Shields \& Lujan, 2018) and subsequently on their education.

Newcomer is a particularly Canadian term, used by Statistics Canada, that designates immigrants who have come to Canada within the last five years, whereas the general term immigrant is unrelated to length of residence in Canada. According to the 2016 Census, 489, 160 youth between the ages of 15 and 34 migrated to Canada between 2011 and 2016 (Statistics Canada, 2019i). Again, lack of distinction between newcomer and immigrant youth in studies clouds statistics and our understanding of their needs. Like those who come to Canada on their own, without the support of family, newcomer youth face substantially greater challenges than those who have lived in Canada for more than five years. Due to the lack of specificity in the literature and statistics regarding length of residence in Canada, we are constrained here to use the term immigrant youth.

Immigrant youth come to Canada from around the world and are characterized by a variety of races, languages, cultures, socioeconomic status, and culturally determined gender roles, all of which enter into their success in Canadian schools and the workforce. The top five ethnic origins ${ }^{1}$ for first-generation Canadians 15 to 34 years old are Chinese, East Indian, Filipino, English, and French. The majority of immigrant youth are racialized. In the 2016 census, approximately $79.2 \%$ of newcomer youth ages 15 to 34 identified as racialized (Statistics Canada, 2019b), an increase of 6.8\% since the 2006 census (Statistics Canada, 2014). In descending order, the most frequently reported racial identities for immigrant youth in 2016 were South Asian, Chinese, black, Filipino, Latin American, Arab, Southeast Asian, West Asian, Korean, and Japanese (Statistics Canada, 2019b).

Immigrant youth 15 to 35 make up $21 \%$ of the working youth population of Canada (Statistics Canada, 2019f). Compared to native-born youth, they have a lower employment rate and a higher unemployment rate (table 1). The majority of immigrant youth work in construction, manufacturing, administration, waste removal, education, healthcare, retail, clothing stores, professional and technical support, and accommodations and food services (Statistics Canada, 2019d). Many of these are low-skilled, low-wage jobs.

\footnotetext{
${ }^{1}$ This list is for both single and multiple ethnic origins reported.
} 
Nichols, Ha, and Tyyskä

Table 1. Employment and Unemployment Rates of Newcomer* and Native-born Canadian Youth, 2016

\begin{tabular}{|l|c|c|c|c|}
\hline & \multicolumn{2}{|c|}{$15-24$} & \multicolumn{2}{c|}{$25-34$} \\
\hline & Newcomers & Nonimmigrants & Newcomers & Nonimmigrants \\
\hline Employment rate (\%) & 38.3 & 54.3 & 68.8 & 81.0 \\
\hline Unemployment rate (\%) & 16.7 & 15.2 & 11.1 & 7.4 \\
\hline
\end{tabular}

*Arrived in Canada between 2011 and 2016

Source: Statistics Canada, 2019f

\section{Immigration and Settlement Policies and Programs}

In addition to humanitarian concerns such as providing a safe haven for refugees, the impetus behind Canada's immigration system is to counteract the country's aging workforce, declining birthrate, and subsequent shortage of skilled workers (Shields \& Bauder, 2015). To fulfill the latter mission, in keeping with the long-held belief that immigrants increase the GDP (Larocque, 2013), Canada uses a merit-based immigration system that awards points for attributes such as education, age, skills, knowledge of Canada's official languages, and health. This meritbased system is more just than discriminatory policies in force from 1867 to the 1960s, which selected immigrants who fit the idealized image of Canada as a white, English-speaking nation (Kaduuli, 2011; Nichols \& Tyyskä, 2015). However, the prioritization of immigrants who can increase the GDP inevitably leads to discrimination based on gender, age, and other factors (Nichols, 2018). Moreover, insufficient settlement services are inconsistent with the point system and its stated intentions. While youth is considered an advantage because young people will have more years to contribute to the Canadian economy, settlement services for this age group are insufficient to support their transition into society and the workforce. School-age youth receive inadequate educational supports, while adult immigrants of all ages face difficulties transferring their foreign credentials and obtaining work in Canada that is at the level of their training and experience (Kaduuli, 2011).

A Joint Centre of Excellence for Research on Immigration and Settlement report by Anisef and Kilbride (2008) found that the majority of supports for newcomer youth do not address their financial insecurity, unemployment, mental health concerns, and lack of diversity in the school curriculum. The authors reported that settlement agencies are underfunded and inadequately staffed. Many are missing "counselling for cultural and/or personal identity, employment services, recreational and social opportunities, assistance for basic needs, English language instruction, school level and school readiness assessments and counselling for religious identity" (Anisef \& Kilbride, 2008, p. 34). Thus, newcomer youth must use their "resourcefulness" to find information across agencies (Centre for Addiction and Mental Health, 2014).

Similarly, the Social Planning Council of Ottawa reported that newcomer youth programs 
lack an appropriate cultural base to help youth come to terms with "balancing their heritage and their roles in the new country" (2010, p. 9). Many immigrant youths feel they must contribute to their household income and take on jobs that conflict with their educational pursuits. To support their transition into the labour market, they require information about training and education and an understanding of employment laws.

A study conducted by Francis and Yan (2016) in the Vancouver area with African newcomer youth found that there are "more gaps than bridges" (p. 79) in social services, including a lack of access to full information, uneven distribution of resources, few programs directed at young newcomers, a lack of coordination among stakeholders who support newcomer youths, and nonrenewable funding sources. Many youths in their study indicated that they were encouraged to take part in mainstream youth programs, but they did not feel welcome there and did not trust the settlement and social welfare system.

A recent CERIS knowledge synthesis report on immigrant youth in Canada by Shields and Lujan (2018) explores gaps in immigration and settlement services. The authors found that immigrant youth face many barriers to integration, including cultural biases on the part of service providers, lack of housing, and inadequate transportation to access education, employment, and social and settlement services. Immigrants under the age of 24 are overrepresented among the homeless population. Toronto's 2018 Street Needs Assessment (City of Toronto, 2018) found that $46 \%$ of the youth population in city-administered shelters were migrants.

\section{Education}

\section{Language}

Mainstream acculturation - a process of learning and adapting to dominant social norms-is essential for success in school and at work. Language is the lifeline of our lived experiences (Chuang, 2010) and a critical component of acculturation for immigrant youth, whose adaptation to Canada is more difficult if they migrate as adolescents, when language learning becomes progressively more difficult (Hartshorne, Tenenbaum, \& Pinker, 2018). Jia, Gottardo, Chen, Koh, and Pasquarella (2016) studied Ontario adolescents from China and confirmed a reciprocal relationship between English language proficiency and acculturation.

Among immigrant youth ages 15 to 34 who migrated to Canada between 2011 and 2016, 76\% spoke neither English nor French at home (Statistics Canada, 2019g), pointing to their urgent need to acquire skills in at least one of Canada's two official languages. Hieu Van Ngo (2007) writes, "There is a widening incongruence between the complexity of the needs of ESL learners and the availability of ESL [English as a Second Language] services in Canadian schools.... School boards across Canada have steadily reduced ESL services over the years. . . Stringent resource allocations for ESL services has resulted in limited language instruction and support services for ESL learners" (p. 3). Ngo notes that it takes five to seven years to develop the cognitive academic language proficiency (CALP) skills that are necessary for success in secondary and postsecondary education, and that inadequate ESL services in schools results in failure to achieve on par with native-English-speaking peers from primary school through university and an increased dropout rate. In Canada, responsibility for education is delegated to the provinces. 
However, Ngo argues that section 15 of the 1982 Canadian Charter of Rights and Freedoms guarantees every individual the right to equality and that therefore adequate ESL instruction is a federal right.

While it appears that schools are not meeting the language needs of immigrant youth, it must be acknowledged that the high number of immigrants in some school districts has placed a very large burden on schools in an era of reduced school funding. By way of example, here we will examine the situation in Ontario, where $29.1 \%$ of the population-the highest of any province - is foreign born (Government of Ontario, 2017). In $201763 \%$ of Ontario's elementary schools and 58\% of secondary schools had English language learners (ELLs), but only 38\% of English-language elementary schools had ESL teachers (People for Education, 2017). Moreover, $20 \%$ of elementary schools and $31 \%$ of secondary schools have no formal process for identifying ELL students (People for Education, 2015), which is the first step to placing students in ELL services.

Ontario schools are allocated \$3,920 per ESL student for their first year in Canada, decreasing over the next three years. But schools with small numbers of immigrant studentsaccounting for one-third of Ontario schools with ELL students - may not have funds to hire an ESL instructor. Thus $76 \%$ of Ontario elementary schools with low ELL populations have no ESL teacher (People for Education, 2017), creating unequal learning opportunities for those students based on where they live. There is no requirement that the funds allocated for ELL students be spent on them, nor provisions for the extra cost of educating ELL students in schools with a higher density of immigrants (Elementary Teachers Federation of Ontario [ETFO], 2017).

In sum, the Elementary Teachers' Federation of Ontario (2017) reports, “Ontario's funding for ESL falls far short of what is needed in four key respects: the determination of which students count for funding purposes; the time period over which additional funding is provided; the level of funding relative to need; and the absence of a standard of competence in English to which ESL funding is targeted" (p. 47). Compounding the challenge faced by school districts, many immigrant children and youth come from countries with poorly developed education systems or where schooling has been interrupted by war and lack age-appropriate academic skills in their first language. Language deficits that begin in elementary school at the critical age of cognitive development carry through to secondary school and become magnified as the demands of the curriculum increase at each level. Immigrant youth who have not received adequate ESL support may never acquire the skills to take university preparatory courses in high school, lessening their chances of university admission; or, once admitted to university they may find that they lack the skills for success at that level (Organisation for Economic Co-operation and Development, 2015).

For immigrants over age 18, the Language Instruction for Newcomers to Canada (LINC) program, sponsored by Citizenship and Immigration Canada, offers free language classes and establishes national proficiency benchmarks in English and French for newcomers at the beginner, immediate, and advanced levels (Government of Canada, 2018). The purpose of the LINC program is to give adults language skills for the labour market. A 2010 Centre for Community-Based Research report on the Waterloo Region in Ontario noted that many LINC participants found that class sizes were too large to practice verbal communication and that there was a lack of evening and weekend classes. 
Nichols, Ha, and Tyyskä

\section{Streaming of Immigrant Youth in High School, College, and University}

"Streaming" or "tracking" refers to the practice of dividing school programs into two or more sequences of courses that prepare students for either work in practical trades immediately after high school or some form of postsecondary education. In Ontario, grade 9 and 10 courses are classified in three streams: "essentials" (local workplace programs), "applied" (for colleges), and "academic" (university). Once students are placed in a lower stream, it is difficult to switch to the university stream because they lack the prerequisite preparation for courses such as higher-level math and science. Thus, streaming plays a major role in young people's later career choices, salaries, and overall socioeconomic success.

Newcomer youth are placed in either English language development (ELD) programs, ESL classes, or mainstream programs without language support based on their perceived skill levels (Selimos \& Daniel, 2017). As with ESL instruction, adequate preparation for later academic challenges needs to begin in elementary school. Absent this early adequate education, students' choices become increasingly restricted.

Although streaming is a common practice in many countries, it is controversial because there is evidence that streaming begins in elementary school and is influenced not only by perceptions of a child's intellectual capacity, but by factors such as race, language, country of origin, and poverty (Chiu, Chow, \& Jon, 2017). Thus, it can be viewed as a form of internal segregation within schools accompanied by stigmatization as students on the lower track learn only with others who are considered low achievers. Early streaming may fail to provide students with a level of academic support and challenge to overcome early deficits, such that by high school the postsecondary academic track is closed to them. Sweet, Anisef, Brown, Walters, and Phythian (2010) write,

Lower track classrooms are typically characterized by less experienced teachers and low teacher expectations (Richardson, 1989; Katz, 1999); less challenging curricula and lower-level learning materials (Callahan, 2005); and student complaints of boredom and low levels of engagement (Berends, 1995). These factors have detrimental impacts on student achievement and prospects for postsecondary education. Indeed, students enrolled in lower ability streams are less likely to complete high school or pursue and complete postsecondary education than those in higher ability tracks (p. 14)

Placement of immigrant youth in lower streams may add to the many difficulties they face in school that limit their potential future options. Sweet et al. (2010) found that streaming of newcomer youth in Toronto depends on their country or region of origin. In their study they discovered that $82 \%$ of youth from Europe and $87 \%$ from Eastern Asia were placed in the academic stream, compared to 38\% of youth from the Caribbean and 52\% from Africa (p. 26). In a 2014 special issue of Our Schools/Ourselves titled "Restacking the Deck: Streaming by Class, Race and Gender in Ontario Schools," Grace-Edward Galabuzi reported clear evidence that skin colour and racial stereotypes influence streaming in Ontario schools. He describes racialization as an "act of social 
construction" with a specific purpose: "to maintain the dominance of the White power structure, underpinning an ideology of meritocracy that helps keep in place the current hierarchy of globalizing capitalism" (p. 186). He reports that in the Toronto school district, "Black students are significantly overrepresented in Applied, Essential and Undefined programs" (p. 194), leading to lower rates of graduation and application to postsecondary education.

\section{Racism in Schools}

Students cannot learn and perform adequately in schools where they feel racially judged by school staff or their peers. A hostile school environment impacts grades and graduation rates, which limits postsecondary choices for minoritized immigrant students. Galabuzi (2014) writes, "Because over $75 \%$ of Canada's new immigrants are racialized, the experience of racialization and the reality of racialized poverty also play a role in the experience of immigrant education. Many of these gaps in achievement are in place before school has even begun" (p. 199). Galabuzi describes the alienation that racialized students feel in a Eurocentric curriculum and calls for a more inclusive program of instruction. He describes racism as an officially concealed yet powerful force in Canadian society that belies Canada's international image as a "tolerant, culturally pluralist, multi-ethnic and colour-blind society" (p. 201).

Wilson-Forsberg, Masakare, Shizaha, Lafrenière, and Mfoafo-M'Carthy (2018) studied 67 male African immigrants ages 18 to 24 in Southern Ontario and found that they were more likely to leave school early, to not pursue postsecondary education, and to have low grades due to their racial identity and the impact of racism in schools on their learning experience. Their study participants indicated that they frequently dealt with stereotypes of the "black male troublemaker" held by their teachers and guidance councillors and that they had to work hard to show that they were the exception to this notion.

Kayaalp (2014) explored the experience of a small cohort of 7 male and 7 female Turkish immigrant youth in Vancouver schools. She writes that this group of newcomers "struggle with bigger questions of "who they are' under the dynamics of mobility and immigration" (p. 655). She found that Turkish newcomer youth face issues related to focusing on the dominant culture to the extent of forgetting their own culture and history, humiliation due to their cultural background, and islamophobia.

Teachers report that racism directed toward newcomer youth comes from teachers and students. In her Prince Edward Island study on refugee students MacNevin (2012) interviewed teachers and found that racism resulted in isolation and exclusion of refugee children. Teachers reported that students separated themselves by language in the classroom and the cafeteria. They expressed concern about how to support their refugee students and often felt they were "feeling [their] way in the dark" (MacNevin, 2012, p. 57).

\section{Postsecondary Education}

Postsecondary education is an important investment for all Canadians, as it provides a route 
to stable employment and income (Rae, 2018). Canada is one of the most educated nations in the world. Among Canadians 25 to 44 years old, $75 \%$ have some form of postsecondary education (Rae, 2018). Canadians who do not finish high school have a lower rate of employment and median income than college or university graduates (tables 2 and 3). Table 3 shows that income rises steadily with additional years of education, with the biggest increase between college graduates and university graduates, but immigrants who arrived as youth lag behind nonimmigrants in salary at all levels of education.

Table 2: Employment Rate (\%), Ages 25 to 54, 2018

\begin{tabular}{|l|c|c|}
\hline & Born in Canada & Landed Immigrant \\
\hline Less than high school diploma & 61.5 & 60.8 \\
\hline High school diploma & 78.9 & 72.6 \\
\hline $\begin{array}{l}\text { Postsecondary certificate or } \\
\text { diploma }\end{array}$ & 87.3 & 82.2 \\
\hline University graduates & 91.0 & 82.8 \\
\hline
\end{tabular}

Source: Statistics Canada, 2019e

Table 3. Median Income as a Factor of Education and Immigration Status, 2016

\begin{tabular}{|l|c|c|}
\hline & \multicolumn{2}{|c|}{ Medium Income (\$CAN) } \\
\hline & Born in Canada & $\begin{array}{c}\text { Immigrants (age of } \\
\text { arrival 15-24) }\end{array}$ \\
\hline $\begin{array}{l}\text { No certificate, diploma, or } \\
\text { degree }\end{array}$ & 38,119 & 35,833 \\
\hline High school diploma & 45,118 & 39,517 \\
\hline $\begin{array}{l}\text { Trade training program or } \\
\text { apprenticeship }\end{array}$ & 50,515 & 43,579 \\
\hline College & 53,380 & 48,937 \\
\hline University & 75,787 & 65,405 \\
\hline
\end{tabular}

Source: Statistics Canada, 2019a

In their study of 67 newcomer refugees in Toronto, Shakya et al. (2010) found that postsecondary education is important to newcomers, but many had no guidance for navigating the Canadian education system and making a career plan, faced financial hardships, and dealt with lack of acknowledgement of their previous education.

More first- and second-generation immigrants attend university (33\% and 26\%, respectively) than those of the third generation (18\%; Statistics Canada, 2019h), possibly pointing 
to a diminishing importance of education the longer immigrant families are in Canada. Rae (2018) notes that immigrant students' postsecondary education attendance is not related to household income or parental educational attainment; rather these youth are determined in their attempts to achieve intergenerational mobility. Picot \& Hou (2012) found that immigrant youth are more likely to be expected by their parents to attend postsecondary education than native-born Canadian youth and to have parents with postsecondary credentials. These observations are consistent with the higher education of recent immigrants in the economic class, who are recruited for their education and skills - values that they pass on to their children.

Immigrant youth who are at risk for not completing high school or postsecondary education include those who migrated at a later age, which can force young immigrants to begin their working life before they are ready. Newcomer youth today face additional hardships due to neoliberal economic policies that have resulted in a high poverty rate and social exclusion, including in schooling (Anisef, Brown, Phythian, Sweet, \& Walters 2010).

\section{Combining Education and Work}

Few studies have explored the challenges of newcomer youth who combine education and work (see Lauer, Wilkinson, Yan, Sin, \& Tsang, 2012; Kunz, 2003; Kilbride, Anisef, BaichmanAnisef, \& Khattar, 2004). Shalileh (2017) found that newcomer youth are less likely than nativeborn youth to be employed while in school. Lauer et al. (2012) reported that only $25 \%$ of newcomer youth worked during high school, compared to $60 \%$ of native-born youth, reflecting the great importance that immigrant families place on education (Rae, 2018). While not working may leave more time for their studies, work during high school also provides students with cultural experience, job references, job skills, networks to find employment, and work ethics (Cooper \& Guyn Cooper Research Associates, 2018; Taylor \& Krahn, 2013).

In contrast to studies that found that newcomer high school students work less than their native-born peers, Wilkinson (2008) notes that due to having to contribute to family income, newcomer youth work 30 hours a week in addition to attending school. This has significant implications for academic success (Rossiter, Hatami, Ripley, \& Rossiter, 2015). Similarly, Kanu (2008) found that African refugee high school students frequently work to support themselves and their families in Canada or in their home countries. More research and updated data are needed on newcomer youth combining work and education, as both are essential for their future economic survival.

\section{Immigrant Youth in the Workforce}

\section{Lack of Data}

Youth is a critical transition period between childhood and adulthood, and the population of first-generation immigrant youth in Canada is approaching the 1 million mark, indicating that it is vital that we understand the experiences and needs of this group in order to prepare immigrant 
youth for social integration and economic self-sufficiency. But research on the employment experiences of newcomer youth is limited; most studies have focused on the second generation (children of immigrants), rather than those who arrived in Canada as children or youth (Wilkinson, 2008). In one of the few recent studies on newcomer youth, Selimos and George (2018) studied the newcomer experience as a whole of youth 15 to 24 years old in Windsor, Ontario. They report mixed employment experiences for this group. Some participants clearly articulated that their parents wanted them to focus on school rather than working. Others wanted to work, particularly part-time, as paid work allowed them to contribute to the family income. Wilkinson, Yan, Tsang, Sin, \& Lauer, (2012) note that there are few studies on newcomer youths' transition from school to work; rather the studies on newcomer youth focus on other aspects of their integration, including mental health and language skills.

\section{The Impact of Neoliberalism on Employment and Immigrant Services}

The advent of neoliberalism in the 1980s brought deep changes to Canada's long-standing commitment to the welfare of its citizens in an effort to cut government spending on social programs. A new ideal of a self-sufficient citizenry came to replace the social thinking in place since the 1940s, and the economic burden of adverse life events shifted from the government to individuals. The new ideal prioritized corporate economic profit over individual welfare. Under neoliberalism government social supports, including social welfare and immigrant settlement services, have been downgraded while the labour market shifted to a profit model characterized by precarious work (Root, Gates-Gasse, Shields, \& Bauder 2014; Nichols, 2018).

These changes have had a significant impact on the newcomer population. While Canada continues in its mission of aiding refugees, neoliberalism has resulted in difficulties for immigrants integrating into the labour market, worse economic fates, and fewer supports for settlement services (Root et al., 2014). For newcomer youth the result is high unemployment, precarious employment, poverty, and frustration over the mismatch between immigration policy (which seeks immigrants who will contribute to the economy) and the precarious labour market (Shields, Rahi $\&$ Scholtz, 2006). The unemployment rate stands at $16.7 \%$ for newcomer youth 15 to 24 years old and $11.1 \%$ for 25- to 34-year-olds who arrived between 2011 and 2016 (Statistics Canada, 2019f), compared to $15.2 \%$ and $7.4 \%$ for native-born youth. The poverty rate for first-generation Canadians 18 to 24 was $33.4 \%$ according to the 2016 census, compared to $12.8 \%$ for native-born Canadians in the same age group (Statistics Canada, 2018j). High unemployment and precarious employment lead to a cycle of low-wage jobs, periods of no income, and socioeconomic hardship, added to preexisting barriers experienced by most newcomers and most youth.

The neoliberal paradigm has led to funding cuts to immigrant services (Nichols, 2018). In a review of newcomer youth supports in Newfoundland, Li, Que, \& Power (2017) found that there were some effective supports for newcomer youth, but weak collaboration between schools and community organizations, seen in a lack of transportation to and from school; insufficient academic bridging programs to help students develop literacy, math, and other skills; and inadequate career counselling. These insufficiencies in funding and service delivery compromise newcomer youths' social and labour market integration.

The shortcomings of Canada's supports for new immigrants impose changes on households 
and family structures as they attempt to navigate a broken system. Shakya et al. (2010) report that newcomer refugee youth take on more family responsibilities, particularly if they arrived without one parent, "becom[ing] interpreters, service navigators and caretakers for their families" (p. 70). Given the hardships their parents face as they attempt to enter the labour market, some youth become the main breadwinner in their household. Shakya et al. (2010) write that "juggling these new and multiple family responsibilities in Canada can be 'overwhelming' for refugee youth and can 'overshadow' their educational aspirations and responsibilities" (p. 70). Their findings were similar to those of Guruge et al. (2015) in their art-based (photovoice) research with newcomer youth. They observed significant role changes after families arrived in Canada, rapid transitions from adolescence to adulthood due to changes in household responsibilities, and youth who supplemented the household income with their work.

\section{Transfer of Foreign Credentials}

"Foreign credentials" refers to education and school transcripts, skills training, work experience, and job references obtained in the home country. The challenge for all newcomers, including youth, is to convince Canadian educational institutions and employers that they have the claimed credentials and that they are on par with those of Canadians. Foreign work credentials are assessed by various regulatory bodies depending on the profession (Fulton, Pullen-Sansfaçon, Brown, Éthier, \& Graham, 2016). Credentials are evaluated based on their relevancy for Canadian society and the entry requirements for some professions (Houle \& Yssaad, 2010).

For school-age youth, rejection of education credentials can result in loss of time at a critical point in their lives when their Canadian-born peers are finishing school and transitioning to work. Many newcomer youths have to repeat university courses they took in their homeland, or even return to high school prior to being considered for university admission. For those who seek to join the workforce, if their credentials are rejected, they may be forced to work in low-wage, low-skill, and precarious forms of labour (Nichols, 2018).

Obstacles to acceptance of foreign credentials include language barriers (translation of documents), assumptions about the superiority of Canadian schools and workplace standards to those in the Global South, racial and ethnic prejudice, and the complexity of the credentialing process. For work credentials, newcomers must first determine the licensing body and then produce documents while navigating language and cultural barriers. Fulton et al. (2016) report, "Once engaged in the pursuit of foreign credential recognition, the participants encountered a myriad of external challenges including: bureaucratic red tape, difficulty obtaining required documentation from their countries of origin, and a lack of guidance and information about the credentialing process" (p. 74). Houle \& Yssaad (2010) found that difficulties surrounding foreign credential recognition have detrimental effects for the labour market and for the societal engagement of newcomers in Canada.

Refugee youths encounter additional obstacles with credentialing. Wilkinson et al. (2012) note that they may have experienced educational disruptions due to conditions in their home country and have difficulty providing documents for a number of reasons. The home country educational institution may no longer be in existence or their records may have been lost. 
Wilkinson et al. report that there are "documented cases where the new regime has destroyed the educational records of some citizens, particularly those who are identified as 'enemies' to the new government" (p. 41).

The credentialing issue in Canada has not yet received the attention it deserves, and most research on credentialing has studied older workers. More attention is needed to the credentialing needs of the newcomer youth population to avoid loss of critical years of education and employment (Wilkinson et al., 2012).

\section{Discrimination in Hiring and on the Job}

The hostility that newcomer youth face in the Canadian education system on the basis of their immigration status, race, language, culture, and other identity factors continues when they enter the job market (Ontario Federation of Labour [OFL], 2014). Discrimination may account for their higher rate of unemployment (OFL, 2014). Participants in the Windsor, Ontario, study by Selimos and George (2018) reported that they faced discrimination in the labour market due to their immigration status and non-Western name. Some articulated being locked out of the labour market altogether, while others reported working at low-skilled jobs, often in family restaurants or alongside other immigrants and temporary workers in greenhouses and other work that Canadians tend to avoid. Those jobs are more physical in nature and require less English, matching some employers' view of immigrant youth as lacking job and language skills. Placing newcomer youth in low-skilled, low-wage jobs with little opportunity to learn new skills leads to a long-term cycle of precarity and poverty (Nichols, 2018).

A 2014 CivicAction report found that newcomer youth are part of a large cadre of youth who frequently experience structural discrimination and racism in job recruitment and screening and holding a job, including youth who are racialized, in poverty, dealing with the criminal justice system, or in foster care, and Aboriginal, LGBTQ, and youth with disabilities. The report notes that many employers believe that this group of youths "have negative attitudes, lack a work ethic, or lack motivation to do entry-level jobs" (p. 6). Cooper and Cooper Research Associates (2018) report that dual immigrant and racialized statuses create an additional obstacle to employment.

Social networks are critical to finding employment (Selimos \& George, 2018; Fresh Voices, 2018). If youths' social networks are limited due to prejudice and discrimination, their access to adequate work is limited (Taylor \& Krahn, 2013).

\section{Workplace Exploitation}

Exploitation in the workplace refers to unfair treatment of workers with respect to job conditions such as wages and hours for the benefit of employers, especially to increase profits (Lapon, 2011). The growth of precarious employment and lower wages under neoliberal economic policies creates vulnerability to exploitation for workers in the form of wages that are beneath workers' skills, forced overtime, unrecorded wages (payment under the table), unpaid or late wages, lack of breaks required by law, no vacation pay, and the growing trend of unpaid or lowwage work-integrated learning (WIL) jobs that do not give students job skills (Turcotte, Nichols, \& Philipps, 2016). To illustrate the exploitative nature of these deliberate employer strategies, 
employers portray unrecorded cash wages as a way for employees to save money on taxes, but in fact it is the employer who benefits from lower taxes, while workers who accept unrecorded cash pay are ineligible for Employment Insurance and other social supports.

Newcomer youth are especially vulnerable to workplace exploitation due to their lack of knowledge of Canadian employment standards such as the minimum wage, maximum hours, and overtime pay and a lack of English competence to learn those standards and negotiate fair working conditions with their employer. Many newcomer youths must shoulder the burden of supporting themselves and extended family members in Canada and in their home country, while also dealing with the pressures of school. They are desperate for work and afraid to protest exploitive conditions for fear of losing their job (Francis \& Yan, 2016).

Social isolation and employer prejudices around immigrants, race, language, and culture that categorize newcomer youth as having little potential reinforce vulnerability to exploitation. In 2019 the Toronto Globe and Mail (Tomlinson, 2019) reported that recruiters and immigration consultants charged 2,000 immigrants large sums of money for referring them to jobs in Canada, with employers also receiving substantial kickbacks, a practice that is illegal in Canada. One international student reported paying $\$ 8,000$ dollars to work at a Subway in British Columbia. British Columbia immigration consultant Shivdev Parmar indicated that employers had approached him offering jobs for immigrants for a fee of $\$ 20,000$ per worker. Another international student was offered a job at a fast-food chain for $\$ 40,000$, payable in installments. International students who accept such offers then find themselves mired in long-term debt to immigration consultants and employers - on top of their tuition fees - and stuck in low-wage jobs in hopes of qualifying for permanent residency by accumulating points for their work. British Columbia Minister of Labour Harry Bains described these schemes as "rampant" (Tomlinson, 2019).

The increase in work-integrated-learning programs opens up a new opportunity for exploitation of students. WIL refers to practicums, jobs, and internships that are undertaken for credit at a secondary or postsecondary institution. Often these positions are required for a specific course or major program or for graduation. While these programs are expanding, government and institutional regulations pertaining to the nature of the work and working conditions are lacking. The result has been the creation of a new class of devalued, underpaid, or unpaid entry-level positions that particularly impact newcomer youth, who are not streamed toward paid WIL positions that include skills training (Turcotte, Nichols, \& Philipps, 2016).

\section{Conclusion}

With close to 3 million immigrant youth between 15 and 35, and given that the main priority of Canada's immigration system is to ensure an adequate future supply of skilled workers, this large population merits further study and effective services to ensure their transition from school to the labour market. The picture for newcomer youth in Canada is not entirely bleak, as attested by the fact that more newcomer youth go to college or university than native-born Canadians. However, this study identified several problem areas that interfere with immigrant youths' success at school and work, including insufficient and underfunded settlement services, lack of diversity in the school curriculum, inadequate ESL services at all levels of schooling, biased 
streaming into the lowest educational track in high school, difficulties with foreign school transcripts and work credentials, and employers' prejudice and discrimination. The number and magnitude of these systemic impediments create significant obstacles for immigrant youth.

The following policy recommendations would contribute to correcting some of these challenges.

1. Settlement services: Establish comprehensive, culturally appropriate, fully funded settlement programs directed at youth, focusing on basic needs (housing, transportation, healthcare, etc.), preparing newcomer youth for the Canadian school system, and employment services, along with improved coordination among service agencies. Settlement programs should include education in Canadian labour laws to reduce workplace exploitation.

2. ESL services: All newcomer students should be assessed for English proficiency and placed in levelled ESL instruction, with clear exit criteria for placement in mainstream classes. ESL support should begin in elementary school and continue until students have grade-level CALP skills - up to 5 to 7 years. Expanded ESL classes are also needed for older youth outside the school system. It is clear that greater funding of ESL instruction is needed.

3. Educational streaming: Eliminate streaming based on race, language, national origin, and other biases and delay streaming of immigrant youth to give them the benefit of additional education and language instruction. Teachers and administrators need to become aware of the long-term effects of streaming immigrant students below their intellectual potential and provide support to allow their potential to emerge.

4. Discrimination and racism in schools: Initiate a more diverse, non-Eurocentric curriculum that is relevant for all students and antiracism programs for students and staff.

5. Education and work credentials: Establish consistent national standards for evaluating foreign school transcripts and work requirements for specific professions and a central credentialing agency. At present the legal, medical, trade, and other professions have separate assessment processes. Establishing a single entity with consistent standards and procedures would facilitate credentialing for newcomers as well as for educational institutions, employers, and licensing boards (Houle \& Yssaad, 2010).

6. Work-Integrated-Learning Programs: (a) Establish consistent standards regarding the purpose and conditions of WIL placements so that students are engaged in meaningful, paid skills training. (b) Regulate enforcement of employment standards in WIL programs. (c) Train guidance and employment counsellors to avoid streaming immigrant youth into unpaid, unskilled WIL placements.

7. Workplace exploitation: (a) Increase oversight of sectors that employ large numbers of immigrants to ensure that federal and provincial employment standards are being implemented. (b) Educate newcomer youth and their parents about Canadian labour laws and workers' rights. 
Nichols, Ha, and Tyyskä

8. Mentorship: Institute mentorship programs in secondary schools, colleges and universities, and settlement organizations to help immigrant youth adapt to Canadian society, form social networks, and become established in the labour market.

9. Coordinated, sustainable services: To ensure efficient use of resources, encourage active collaboration among stakeholders, avoid duplication of services in the same geographic area, and design funding to cover long-term needs rather than nonrenewable funding for individual projects.

Policy changes can only succeed if there are simultaneous efforts to change societal attitudes surrounding immigrants, race, and ethnicity. Education in Canada's fundamental values of equality and a pluralistic society is the key to creating deep social change that permeates all levels of government, education, and the workforce. It is immigrant youth who will meet Canada's need for skilled workers to support economic expansion. For them to fulfill this mandate will necessitate changes in schools and the workplace and increased government commitment to their full integration into Canadian society. 
Nichols, Ha, and Tyyskä

\section{References}

Anisef, P., Brown, R. S. Phythian, K., Sweet, R., \& Walters D. (2010). Early school leaving among immigrants in Toronto secondary schools. Canadian Review of Social Policy, 47(2), 103-128.

Anisef, P., \& Kilbride, K. M. (2008). The needs of newcomer youth and emerging "best practices" to meet those needs: Final report. Toronto: Joint Centre of Excellence for Research on Immigration and Settlement (CERIS). Retrieved from https://www.library.yorku.ca/find/Record/2589727

Canadian Council on Social Development (2006). The progress of Canada's children and youth. Retrieved from https://www.ccsd.ca/resources/ProgressChildrenYouth/index.htm

Centre for Addiction and Mental Health, in collaboration with the Children's Aid Society of Toronto. (2014, July). Hidden in our midst: Homeless newcomer youth in TorontoUncovering the supports to prevent and reduce homelessness. Retrieved from http://www.childwelfareinstitute.torontocas.ca/sites/childwelfareinstitute/files/25\%20Hid den\%20in\%200ur\%20Midst\%20-\%20Homeless\%20Newcomer\%20Youth.pdf

Centre for Community-Based Research (2010, April). An environmental scan of English language services in Waterloo region. Retrieved from https://projects.communitybasedresearch.ca/projects/9095_-environmental-scan-ofenglish-language-services-for-newcomers-in-waterloo-region/

Chiu, M. M., Chow, B. W.-Y., \& Joh, S. W. (2017). Streaming, tracking and reading achievement: A multilevel analysis of students in 40 countries. Journal of Educational Psychology, 109(7), 915-934. Retrieved from https://psycnet.apa.org/record/2017-09889001

Chuang, S. S. (2010). New Start for Youth Study: An examination of the settlement pathways of newcomer youth. Retrieved from http://communities4families.ca/wpcontent/uploads/2014/08/New-Start-for-Newcomer-Youth-CISSA-ACSEI-Report.pdf

City of Toronto. (2018). Street needs assessments 2018. Retrieved from https://www.toronto.ca/wp-content/uploads/2018/11/99be-2018-SNA-Results-Report.pdf

CivicAction (2014, August). Escalator jobs for youth facing barriers: Companies and youth moving up in the world. Retrieved from https://www.civicaction.ca/wpcontent/uploads/2015/08/EscalatorReport2014.pdf

Cooper, M., \& Guyn Cooper Research Associates (2018, May 31). Improving employment outcomes for vulnerable youth. Retrieved from http://www.burnsfund.com/wpcontent/uploads/2018/06/Calgarys-Vulnerable-NEET-Youth_-June-2018.pdf

Deckers, C. M., \& Zinga, D. (2012). Locating home: Newcomer youths' school and community engagement. Canadian Journal of Education, 35(3), 30-47.

Elementary Teachers Federation of Ontario. (2017, August). Shortchanging Ontario students: An overview and assessment of education funding in Ontario. Retrieved from http://www.etfo.ca/AboutETFO/Publications/PositionPapers/PositionPapersDocuments/S hortchanging\%20Ontario\%20Students\%20-\%20An\%20overview\%20and\%20assessment $\% 20$ of\%20education\%20funding\%20in\%20Ontario.pdf 
Francis, J., \& Yan, M.-C. (2016). Bridging the gaps: Access to formal support services among young African immigrants and refugees in Metro Vancouver. Canadian Ethnic Studies, $48(10), 77-100$.

Fresh Voices (2018, May) Employment, mobility, and integration: Experiences of immigrant and refugee youth in Metro Vancouver. Retrieved from https://www.vancouverfoundation.ca/sites/default/files/publications/Fresh-VoicesMobility-Study-Final.pdf

Fulton, A. E., Pullen-Sansfaçon, A., Brown, M., Éthier, S., \& Graham, J. R. (2016). Migrant social workers, foreign credential recognition and securing employment in Canada: A qualitative analysis of pre-employment experiences. Canadian Social Work Review, $33(1), 65-86$.

Galabuzi, G.-E. (2014). Race and the streaming of Ontario's children and youth. In Restacking the deck: Streaming by class, race and gender in Ontario schools. Our Schools, 23(2), 185-226.

Government of Canada. (2018). Language classes funded by the Government of Canada. Retrieved from https://www.canada.ca/en/immigration-refugeescitizenship/services/new-immigrants/new-life-canada/improve-englishfrench/classes.html

Government of Ontario. (2017). 2016 Census highlights: Factsheet 8. Ministry of Finance. Retrieved from https://www.fin.gov.on.ca/en/economy/demographics/census/cenhi168.html

Gros, H., \& Song, Y. (2016). "No life for a child": A roadmap to end immigration detention of children and family separation. Retrieved from https://ihrp.law.utoronto.ca/sites/default/files/PUBLICATIONS/ReportNoLifeForAChild.pdf

Guruge, S., Hynie, M., Shakya, Y., Akbari, A., Htoo, S., \& Abiyo, S. (2015). Refugee youth and migration: Using arts-informed research to understand changes in their roles and responsibilities. Forum: Qualitative Social Research, 16(3).

Hartshorne, J., Tenenbaum, J., \& Pinker, S. (2018, August). A critical period for second language acquisition: Evidence from 2/3 million English speakers. Cognition, 177, 263277. Doi: https://doi.org/10.1016/j.cognition.2018.04.007

Hayes, D. (2013, August 17). Program helps 'unaccompanies minors' navigate Canada's refugee process. https://www.thestar.com/news/insight/2013/08/17/program_helps_unaccompanied_minor s_navigate_canadas_refugee_process.html

Houle, R., \& Yssaad, L. (2010). Recognition of newcomers' foreign credentials and work experience. Ottawa: Statistics Canada. Retrieved from https://www150.statcan.gc.ca/n1/pub/75-001-x/2010109/article/11342-eng.htm\#cont

Jia, F., Gottardo, A., Chen, X., Koh, P., \& Pasquarella, A. (2016). English proficiency and acculturation among Chinese immigrant youth in Canada: A reciprocal relationship. Journal of Multilingual and Multicultural Development, 37(8), 774-782.

Kaduuli, S. (2011). Pointers to discriminatory Canadian immigration policies. Transnational Social Review, 1(1), 115-120. 
Nichols, Ha, and Tyyskä

Kanu, Y. (2008). Educational needs and barriers for African refugee students in Manitoba. Canadian Journal of Education, 31(4), 915-940.

Kayaalp, D. (2014). Education inclusion/exclusion of Turkish immigrant youth in Vancouver, Canada: A critical analysis. International Journal of Inclusive Education, 7, 655-668.

Kilbride, K. M., Anisef, P., Baichman-Anisef, E., \& Khattar, R. (2004). Between two worlds: The experiences and concerns of immigrant youth. http://ceris.metropolis.net/Virtual\%20Library/other/ kilbride2.html

Kunz, J. L. (2003). Being young and visible: Labour market access among immigrant and visible minority youth. Retrieved from: http://files.eric.ed.gov/fulltext/ED505319.pdf

Lapon, G. (2011, September 28). What do we mean by exploitation? SocialistWorker.org. Retrieved from https://socialistworker.org/2011/09/28/what-do-we-mean-exploitation

Larocque, C. (2013, October 7). For Canada, immigration is a key to prosperity. Globe and Mail. Retrieved from https://www.theglobeandmail.com/report-onbusiness/economy/economy-lab/for-canada-immigration-is-a-key-toprosperity/article14711281/

Lauer, S., Wilkinson, L., Yan, M. C., Sin, R., \& Tsang, A. K. T. (2012). Immigrant youth and employment: Lessons learned from the analysis of LSIC and 82 lived stories. Journal of International Migration and Integration, 13(1), 1-19.

Li, X., Que, H., \& Power, K. (2017). Welcome to "the rock": Service providers' views on newcomer youth integration in Newfoundland and Labrador. Journal of International Migration and Integration, 18(4), 1105-1122.

MacNevin, J. (2012). Learning the way: Teaching and learning with and for youth from refugee backgrounds on Prince Edward Island. Canadian Journal of Education, 35(3), 48-63.

Moyser, M. (2017). Women and paid work. Ottawa: Statistics Canada. Retrieved from https://www150.statcan.gc.ca/n1/pub/89-503-x/2015001/article/14694-eng.htm

Ngo, H. V. (2007). Toward quality ESL education. TESL Canada Journal, 24(2), 1-22.

Nichols, L. (2018). Newcomer women's experiences of immigration and precarious work in Toronto. Women's Health and Urban Life, 14(1): 7-30.

Nichols, L. (2019). Young women: Navigating the education-employment divide. In L. Nichols (Ed.), Working women in Canada: An intersectional approach. Toronto: Women's Press.

Nichols, L., \& Tyyskä, V. (2015). Immigrant women in Canada and the United States. In J. Shields and H. Bauder (Eds.), Immigrant experiences in North America: Understanding settlement and integration (pp. 248-272). Toronto: Canadian Scholars' Press.

Ontario Federation of Labour. (2014, February 27). Addressing youth: Unemployment and underemployment. Submission to the Premier's Council on Youth Opportunities. Retrieved from https://ofl.ca/wp-content/uploads/2014.02.27-SUBUnderEmployment.pdf

Organisation for Economic Co-operation and Development. (2015). Helping immigrant students to succeed at school — and beyond. Retrieved from https://www.oecd.org/education/Helping-immigrant-students-to-succeed-at-school-andbeyond.pdf 
Nichols, Ha, and Tyyskä

People for Education. (2015). Ontario's schools: The gap between policy and reality. Retrieved from https://peopleforeducation.ca/wp-content/uploads/2017/10/P4E-Annual-Report2015.pdf

People for Education. (2017). Competing priorities: People for Education annual report on Ontario's publicly funded schools 2017 . Retrieved from https://peopleforeducation.ca/wp-content/uploads/2017/08/P4E-annual-report-2017.pdf

Picot, G., \& F. Hou (2012). Immigrant postsecondary education: A comparison of Canada and Switzerland. Ottawa: Statistics Canada. Retrieved from https://www150.statcan.gc.ca/n1/en/pub/11-626-x/11-626-x2012013eng.pdf?st=LXaugKqK

Rae, J. (2018, February). Making the grade: Immigrant youth in post-secondary education. Ottawa: Crime Prevention Ottawa. Retrieved from http://cciottawa.ca/wpcontent/uploads/Education-Report.pdf

Root, J., Gates-Gasse, E., Shields, J., \& Bauder, H. (2014, October). Discounting immigrant families: Neoliberalism and the framing of Canadian immigration policy change, a literature review. RCIS Working Paper No. 2014/7. Retrieved from https://www.ryerson.ca/content/dam/rcis/RCIS-WP-Root-No2014-7.pdf

Rossiter, M. J., Hatami, S., Ripley, D., \& Rossiter, K. R. (2015). Immigrant and refugee youth settlement experiences: "A new kind of war." International Journal of Child, Youth \& Family Studies, 6(4-1), 746-770.

Selimos, E. D., \& George, G. (2018). Welcoming initiatives on the social inclusion of newcomer youth: The case of Windsor, Ontario. Canadian Ethnic Studies, 50(3), 69-89.

Selimos, E. D., \& Daniel, Y. (2017). The role of schools in shaping the settlement experiences of newcomer immigrant and refugee youth. International Journal of Child, Youth and Family Studies, 8(2), 90-109.

Shakya, Y. B., Guruge, S., Hynie, M., Akbari, A., Malik, M., Htoo, S. . . \& Alley, S. (2010). Aspirations for higher education among newcomer refugee youth in Toronto: Expectations, challenges, and strategies. Refuge, 27(2), 65-78.

Shalileh, H.. (2017). Labour market transition: Barriers and supports for first generation immigrant and refugee youth (unpublished master's thesis). Carleton University.

Shields, J., \& Bauder, H. (2015). Understanding immigration, settlement, and integration in North America. In J. Shields \& H. Bauder (Eds.), Immigrant experiences in North America: Understanding settlement and integration (pp. 11-33). Toronto: Canadian Scholars' Press.

Shields, J., \& Lujan, O. (2018). Immigrant youth in Canada: A literature review of migrant youth settlement and service issues knowledge synthesis report. CERIS. Retrieved from http://ceris.ca/IWYS/wp-content/uploads/2018/09/IWYS-Knowledge-Synthesis-ReportYouth-report-Sept-2018.pdf

Shields, J., Rahi, K., \& Scholtz, A. (2006, May). Voice from the margins: Visible-minority immigrant and refugee youth experiences with employment exclusion in Toronto. CERIS Working Paper No. 47. Retrieved from https://wall.oise.utoronto.ca/resources/Antonie_paper.pdf 
Social Planning Council of Ottawa. (2010, December). Best practices in supporting the integration of immigrant families through small ethno-cultural organizations. Retrieved from https://www.spcottawa.on.ca/sites/all/files/pdf/2010/Publications/Best-PracticesSupporting-Immigran-Families-English.pdf

Statistics Canada. (2014). Data tables, 2016 Census. Catalogue no. 97-562-XCB2006016.

Statistics Canada. (2018, February 7). A portrait of Canadian youth. Retrieved from https://www150.statcan.gc.ca/n1/pub/11-631-x/11-631-x2018001-eng.htm

Statistics Canada. (2019a). Data tables, 2016 Census. Catalogue no. 98-400-X2016253.

Statistics Canada. (2019b). Data tables, 2016 Census. Catalogue no. 98-400-X2016187.

Statistics Canada. (2019c). Data tables, 2016 Census. Catalogue no. 98-400-X2016236.

Statistics Canada. (2019d). Data tables, 2016 Census. Catalogue no. 98-400-X2016358.

Statistics Canada. (2019e). Table 14-10-0087-01. Labour force characteristics of immigrants by educational attainment, annual. DOI https://doi.org/10.25318/1410008701-eng

Statistics Canada. (2019f). Data tables, 2016 Census. Catalogue no. 98-400-X2016286.

Statistics Canada. (2019g). Data tables, 2016 Census. Catalogue no. 98-400-X2016194.

Statistics Canada. (2019h). Data tables, 2016 Census. Catalogue no. 98-400-X2016275.

Statistics Canada. (2019i). Data tables, 2016 Census. Catalogue no. 98-400-X2016191.

Statistics Canada. (2019j). Data tables, 2016 Census. Catalogue no. 98-400-X2016211.

Sweet, R., Anisef, P, Brown, R., Walter, D., \& Phythian, K. (2010, October 6). Post-high school pathways of immigrant youth. Toronto: Higher Education Quality Council. Retrieved from http://www.heqco.ca/SiteCollectionDocuments/Pathways\%20ENG.pdf

Taylor, A., \& Krahn, H. (2013). Living through our children: Exploring the education and career "choices" of racialized immigrant youth in Canada. Journal of Youth Studies, 16(8), $1000-1021$.

Tomlinson, K. (2019, May 31). Employers taking cash from foreign workers seeking permanent resident status in Canada. Globe and Mail. Retrieved from https://www.theglobeandmail.com/canada/article-employers-taking-cash-from-foreignworkers-seeking-permanent-resident/

Turcotte, J. F., Nichols, L., \& Philipps, L. (2016) Maximizing opportunity, mitigating risk: Aligning law, policy and practice to strengthen work-integrated learning in Ontario. Toronto: Higher Education Quality Council of Ontario. Retrieved from http://www.heqco.ca/SiteCollectionDocuments/Maximizing-Opportunity-MitigatingRisk.pdf

Tyyskä, V. (2014). Youth and society: The long and winding road. 3rd ed. Toronto: Canadian Scholars' Press.

Walji, N. (2018, December 30). Shelter aims to help young people on their own adjust to life in Canada. CBS News. Retreived from https://www.cbc.ca/news/canada/refugee-sheltermatthew-house-youth-unaccompanied-transition-1.4922946

Wilkinson, L. (2008). Labor market transitions of immigrant-born, refugee-born, and Canadianborn youth. Canadian Review of Sociology, 45(2), 151-176.

Wilkinson, L., Yan, M. C., Tsang, A. K. T., Sin, R., \& Lauer, S. (2012). The school-to-work transitions of newcomer youth in Canada. Canadian Ethnic Studies, 44(3), 29-44. 
Nichols, Ha, and Tyyskä

Wilson-Forsberg, S., Shizha, E., Masakure, O., Lafrenière, G., \& Mfoafo-M'Carthy, M. (2018). Disrupting an imposed identity or performing the model minority? The pursuit of postsecondary education by young African immigrant men in Southern Ontario, Canada. Race, Ethnicity and Education, 1- 19. DOI: 10.1080/13613324.2018.1497965 